(Vol. VI, Maret 2015 )

\title{
HUBUNGAN ANTARA PENGETAHUAN IBU TENTANG PEMERIKSAAN KEHAMILAN TRIMESTER I DENGAN KUNJUNGAN K1 MURNI DI BPS HANIK SURABAYA
}

\author{
Retno Setyo Iswati \\ Tenaga Pengajar Prodi DIII Kebidanan Universitas PGRI Adi Buana Surabaya
}

\begin{abstract}
ABSTRAK
Salah satu penyebab tingginya angka kematian ibu adalah kurangnya informasi dan pengetahuan ibu hamil mengenai kehamilan dan persalinan. $\mathrm{K} 1$ adalah kunjungan ibu hamil yang pertama kali pada masa kehamilan. K1 di bagi menjadi 2 yaitu K1 Murni dan K1 Akses. Adapun tujuan penelitian yaitu untuk mengetahui hubungan antara pengetahuan ibu tentang pemeriksaan kehamilan pada trimester I dengan kunjungan K1 Murni di Bidan Praktek Swasta Hanik Surabaya.

Teknik penelitian ini adalah observasional, berdasarkan waktunya penelitian ini dikelompokkan dalam penelitian cross sectional. Pengambilan sampel menggunakan total sampling sebanyak $40 \mathrm{ibu}$ hamil dengan instrument kuesioner dan teknik analisis data menggunakan uji product moment dengan tingkat kemaknaan 0,05.

Hasil penelitian didapatkan bahwa dari 40 responden separuh berpengetahuan kurang tentang pemeriksaan kehamilan (50\%) dan sebagian besar responden melakukan kunjungan K1 Murni (70\%). Dari hasil pengujian product moment didapatkan nilai signifikansi sebesar $\alpha$ : 0.029 dan nilai $(r)$ sebesar : 0.345 yang menunjukkan ada hubungan antara pengetahuan ibu tentang pemeriksaan kehamilan pada trimester I dengan kunjungan K1 Murni di Bidan Praktek Swasta Hanik Surabaya

Kesimpulan dari hasil penelitian ini menunjukkan bahwa ibu hamil yang berkunjung di BPS Hanik sebagian berpengetahuan kurang, dan sebagian besar melakukan kunjungan K1 Murni. Terdapat hubungan antara pengetahuan ibu tentang pemeriksaan kehamilan pada trimester I dengan kunjungan K1 Murni di Bidan Praktek Swasta Hanik Surabaya dengan tingkat korelasi yang rendah.

Diharapkan untuk ibu selalu meningkatkan pengetahuan dengan cara membaca atau konsultasi kepada petugas kesehatan.
\end{abstract}

Kata Kunci : Pengetahuan ibu pemeriksaan Kehamilan, Kunjungan K1 Murni

\section{PENDAHULUAN}

Menurut data WHO, sebanyak 99 persen kematian ibu akibat masalah persalinan atau kelahiran terjadi di negara-negara berkembang.. Berdasarkan Laporan Kematian Ibu (LKI) Kabupaten/Kota se Jawa Timur jumlah kematian ibu adalah 627 kasus. Masa kematian terbesar pada masa nifas $48,17 \%$, sedangkan masa hamil dan masa persalinan masingmasing 22,49\% dan 29,35\% (Dinkes Provinsi Jatim, 2011). Salah satu penyebab angka kematian ini adaiah kurangnya informasi dan pengetahuan ibu hamil mengenai kehamilan, persalinan dan pasca persalinan. Kematian ibu juga di warnai oleh halhal nonteknis yang masuk kategori penyebab mendasar seperti taraf pengetahuan, sikap, dan perilaku ibu hamil yang masih rendah, serta melewati pentingnya pemeriksaan kehamilan dengan melihat angka kunjungan pemeriksaan kehamilan 
(K4) yang masih kurang dari standar acuan nasional (Prawirohardjo, 2002).

$\mathrm{K} 1$ adalah kunjungan ibu hamil yang pertama kali pada masa kehamilan $\mathrm{K} 1$ di bagi menjadi 2 yaitu K1 Murni dan K1 Akses. K1 murni adalah adalah jumlah kontak pertama ibu hamil dengan tenaga kesehatan pada umur kehamilan kurang dari 12 minggu, sedangkan K1 Akses adalah jumlah kontak pertama ibu hamil dengan tenaga kesehatan tanpa melihat umur kehamilan . K4 adalah kunjungan ibu hamil yang dimulai dari triwulan pertama 1 kali, triwulan kedua 1 kali dan triwulan ketiga 2 kali. Cakupan $\mathrm{K} 1$ atau juga disebut akses pelayanan kesehatan ibu hamil merupakan gambaran besaran ibu hamil yang telah melakukan kunjungan pertama ke sarana kesehatan untuk mendapatkan pelayanan antenatal. Sedangkan cakupan K4 adalah gambaran besaran ibu hamil yang mendapatkan pelayanan ibu hamil sesuai standar serta paling sedikit empat kali kunjungan, dengan distribusi sekali pada trimester pertama, sekali pada trimester kedua dan dua kali pada trimester ketiga.

Kesenjangan antara cakupan $\mathrm{K} 1$ besar, yang berarti masih banyak ibu hamil yang telah melakukan kunjungan pertama pelayanan antenatal tidak meneruskan kunjungan sehingga kehamilannya lepas dari pemantauan petugas kesehatan. Kondisi tersebut membuka peluang terjadinya kematian pada ibu melahirkan dan bayi yang dikandungnya. Kondisi tersebut harus diantisipasi dengan meningkatkan penyuluhan ke masyarakat serta melakukan komunikasi edukasi yang intensif kepada ibu hamil dan keluarganya agar memeriksakan kehamilannya sesuai standart (Profil Kesehatan, 2010).

$$
\text { Pengawasan }
$$

memberikan antenatal dengan ditemukannya berbagai kelainan yang menyertai kehamilan secara dini, sehingga dapat diperhitungkan dan dipersiapkan langkah - langkah pertolongan persalinannya. Diketahui bahwa janin dalam rahim dan ibunya merupakan satu kesatuan yang saling mempengaruhi, sehingga kesehatan ibu yang optimal akan meningkatkan kesehatan, pertumbuhan, dan pekembangan janin. Ibu hamil dianjurkan untuk melakukan pengawasan antenatal sebanyak 4 kali, yaitu pada setiap trimester, sedangkan trimester terakhir sebanyak dua kali (Ida Bagus Gede Manuaba, 2010). Hal ini menunjukkan masih kurangnya pengetahuan ibu hamil tentang kunjungan awal K1 Murni. Berdasarkan latar belakang di atas, pengetahuan tentang kunjungan awal $\mathrm{K} 1$ murni, bagi ibu hamil sangat mutlak diketahui, karena dengan mengetahui kunjungan awal murni segala resiko yang akan terjadi akan terantisipasi dengan baik. Sehingga peneliti tertarik untuk melakukan penelitian dengan judul "Hubungan antara pengetahuan ibu tentang pemeriksaan kehamilan trimester I dengan kunjungan K1 Murni Di Bidan Praktek Swasta Hanik Surabaya.

Rumusan masalah adalah Adakah hubungan yang signifikan antara pengetahuan ibu tentang pemeriksaan kehamilan trimester I dengan kunjungan K1 Murni di Bidan Praktek Swasta Hanik Surabaya? Sedangkan tujuan penelitian adalah 1) Mengidentifikasi pengetahuan ibu tentang pemeriksaan kehamilan pada trimester I di Bidan Praktek Swasta Hanik Surabaya 2) Mengidentifikasi kunjungan K1 Murni di Bidan Praktek Swasta Hanik Surabaya. 3) Menganalisis hubungan antara pengetahuan ibu tentang pemeriksaan kehamilan trimester I dengan kunjungan K1 Murni di Bidan Praktek Swasta Hanik Surabaya. 


\section{BAHAN DAN METODE}

Dalam penelitian digunakan metode deskriptif , desain penelitian cross sectional dengan populasi semua ibu hamil yang melakukan kontak pertama antenatal K1 di BPS Hanik Surabaya pada bulan April- Juni 2014 sejumlah 40 responden. Sampel yang digunakan adalah total sampling dengan instrument penelitian yaitu kuesioner . Data yang dikumpulkan oleh peneliti berupa data umum (umur, pendidikan, pekerjaan, graviditas, sumber informasi, dan jarak BPS) dan data khusus (ppengetahuan ibu tentang pemeriksaan kehamilan dan kunjungan K1 Murni). Untuk mengetahui adanya hubungan pengetahuan ibu tentang pemeriksaan kehamilan trimester I dengan kunjungan K1 Murni digunakan pengujian dengan menggunakan uji product moment dengan tingkat kemaknaan 0.05. Waktu penelitian April - Juni 2014. Tempat penelitian di BPS Hanik Surabaya.

\section{HASIL DAN PEMBAHASAN}

- Data Umum : Sebagian besar ibu hamil yang melakukan pemeriksaan antenatal pertama kali di BPS Hanik Surabaya adalah : 1). Berumur antara 2025 tahun (45\%), 2). Berpendidikan menengah $(60 \%), \quad 3)$. Tidak bekerja $(75,5 \%)$, 4). Merupakan kehamilan pertama/primigravida $(62,5 \%)$, 5).Mendapatkan sumber informasi dari penyuluhan posyandu $(67,5 \%)$, $6)$. Jarak dari rumah responden ke BPS \pm 500 meter $(52,5 \%)$.
- Data Khusus :

Tabel 1. Distribusi Pengetahuan ibu tentang pemeriksaan kehamilan trimester I

\begin{tabular}{llcc}
\hline No & Pengetahuan & Frekuensi & Persentase \\
\hline 1 & Kurang & 20 & 50,0 \\
2 & Cukup & 16 & 40,0 \\
3 & Baik & 4 & 10,0 \\
\hline & Total & 40 & 100 \\
\hline
\end{tabular}

Dari tabel diatas menunjukkan bahwa dari 40 responden yang periksa kehamilan sebesar $50 \%$ berpengetahuan kurang , $40 \%$ berpengetahuan cukup dan $10 \%$ berpengetahuan baik.

Tabel 2 : Distribusi Kunjungan K1 Murni

\begin{tabular}{llcc}
\hline No & Kunjungan & Frekuensi & Persentase \\
\hline 1 & Tidak K1 Murni & 12 & 30,0 \\
2 & K1 Murni & 28 & 70,0 \\
\hline & Total & 40 & 100 \\
\hline
\end{tabular}

Dari tabel dapat dilihat bahwa dari 40 responden yang periksa kehamilan sebesar $70 \%$ melakukan kunjungan yang pertama kali pada usia kehamilan kurang dari 3 bulan (K1 Murni) yaitu sebanyak 28 responden dan sebesar $30 \%$ melakukan kunjungan pertama pada usia kehamilan diatas 3 bulan.

Tabel 3 : Tabulasi Silang Pengetahuan Ibu Tentang Pemeriksaan Kehamilan Trimester I dengan Kunjungan K1 Murni di BPS Hanik Surabaya

\begin{tabular}{lllllll}
\hline \multirow{3}{*}{ Pengetahuan } & \multicolumn{9}{c}{ Kunjungan } & \multirow{2}{*}{$\begin{array}{c}\text { Tidak K1 } \\
\text { Murni }\end{array}$} & K1 Murni & Total \\
\cline { 2 - 6 } & $\mathbf{n}$ & $\%$ & $\mathbf{n}$ & $\%$ & $\mathbf{n}$ & $\%$ \\
\hline Kurang & 9 & 45,0 & 11 & 55.0 & 20 & 100 \\
\hline Cukup & 3 & 18,8 & 13 & 81.3 & 16 & 100 \\
\hline Baik & 0 & 0 & 4 & 100 & 4 & 100 \\
\hline Total & 12 & 30.0 & 28 & 70.0 & 40 & 100 \\
\hline
\end{tabular}

Berdasarkan tabel diatas menunjukkan bahwa dari total 40 responden , 20 responden yang berpengetahuan kurang melakukan K1 murni sebesar $55 \%$, sedangkan dari 16 responden yang berpengetahuan cukup melakukan K1 murni sebesar $81.3 \%$ 
dan dari 4 responden yang berpengetahuan baik seluruhnya melakukan K1 murni (100\%).

Dari hasil pengujian product moment didapatkan nilai signifikansi sebesar $\alpha$ : 0.029 dan nilai ( $r$ ) sebesar : 0.345 . Nilai a : 0.029 menunjukkan bahwa hipotesa diterima yaitu terdapat hubungan antara pengetahuan ibu tentang pemeriksaan kehamilan pada trimester I dengan kunjungan K1 Murni Di Bidan Praktek Swasta Hanik Surabaya, sedangkan nilai $r$ sebesar 0,345 menunjukkan tingkat korelasi yang rendah artinya terdapat hubungan yang rendah antara pengetahuan ibu tentang pemeriksaan kehamilan pada trimester I dengan kunjungan K1 Murni.

Pembahasan dalam hal ini sesuai dengan tujuan penelitian yaitu 1) Pengetahuan ibu tentang pemeriksaan kehamilan pada trimester I mendapatkan hasil bahwa dari 40 responden yang berpengetahuan kurang sebesar $50 \%$, ibu yang berpengetahuan kurang disebabkan karena kurangnya pemahaman ibu hamil tentang pentingnya pemeriksaan kehamilan meskipun sebagian besar telah mendapatkan informasi dari penyuluhan.. Hal ini ditunjang dari tingkat usia ibu yang sebagian besar berusia antara 20-25 tahun dan berpendidikan SMA, dimana dari segi umur dan tingkat pendidikan teori menyatakan bahwa semakin cukup umur, tingkat kematangan dan kekuatan seseorang akan lebih matang dalam berfikir dan lebih baik pengetahuannya. Hal ini sebagai akibat dari pengalaman dan kematangan jiwanya. ( A Wawan, 2010). 2) Pada kunjungan K1 Murni menunjukkan sebagian besar ibu melakukan kunjungan K1 Murni (70 $\%)$. Cakupan $\mathrm{K} 1$ atau juga disebut akses pelayanan ibu hamil merupakan gambaran besaran ibu hamil yang telah melakukan kunjungan pertama ke fasilitas pelayanan kesehatan untuk mendapatkan pelayanan antenatal. Salah satu factor penyebab tinǵginya cakupan $\mathrm{K} 1$ dipengaruhi oleh jarak ke fasilitas kesehatan yang tidak terlalu jauh, hal tersebut dapat dilihat dari hasil "penelitan yaitu sebagian besar responden berjarak \pm 500 meter $(52,5 \%)$. Seperti yang disampaikan oleh Renova, 2010 bahwa factor penyebab rendahnya kunjungan ibu hamil untuk memeriksakan kehamilannya salah satunya adalah terisolasi karena geografis maupun mereka yang tinggal di daerah kumuh kota. 3) Hasil analisis menggunakan tabulasi silang antara pengetahuan ibu dengan kunjungan K1 Murni dapat diketahui bahwa ibu hamil yang berpengetahuan baik semuanya melakukan kunjungan $\mathrm{K} 1$ Murni (100\%), yang berpengetahuan cukup melakukan kunjungan K1 Murni sebesar $81,3 \%$ sedangkan yang berpengetahuan kurang melakukan kunjungan K1 Murni sebesar 55\%. Dari hasil pengujian product moment didapatkan nilai signifikansi sebesar $\alpha$ : 0,029029 dan nilai (r) : 0.345, maka dapat disimpulkan bahwa ada hubungan yang signifikan antara pengetahuan ibu tentang pemeriksaan kehamilan pada trimester I dengan kunjungan K1 Murni di Bidan Praktek Swasta Hanik Surabaya.

Berdasarkan hasil penelitian dapat diketahui adanya kesesuaian antara penelitian dengan teori yang menyebutkan bahwa dengan pengetahuan yang tinggi maka ibu akan memiliki kesadaran dan keinginan untuk memeriksakan kehamilannya. Pengetahuan sangat berpengaruh terhadap perilaku dan pola pikir seseorang (Notoatmodjo, 2007). Pengetahuan tentang kehamilan yang dimiliki oleh ibu hamil berarti mempengaruhi perilaku ibu dalam melakukan kunjungan ANC sehingga bahaya kehamilan yang tidak diinginkan dapat dihindari. Memiliki pengetahuan tentang kehamilan 
berarti ibu telah mampu mendalami dan menghadapi masalah dalam kehamilan. Ibu yang mempunyai pengetahuan yang baik tentang kehamilanya maka ibu akan mempunyai kesadaran yang tinggi untuk merawat kehamilannya. Salah satu upaya yang dilakukan adalah dengan rutin melakukan pemeriksaan ANC.

Meskipun sebagian ibu hamil berpengetahuan kurang tetapi melakukan kunjungan K1 Murni sebesar $70 \%$ hal tersebut salah satunya dikarenakan factor jarak dari rumah responden ke BPS Hanik Surabaya yang tidak terlalu jauh berjarak \pm 500 meter $(52,5 \%)$. Seperti yang disampaikan oleh Renova, 2010 bahwa factor penyebab rendahnya kunjungan ibu hamil untuk memeriksakan kehamilannya salah satunya adalah terisolasi karena geografis maupun mereka yang tinggal di daerah kumuh kota.

\section{SIMPULAN DAN SARAN}

Dari hasil penelitian dapat disimpulkan bahwa :

1. Sebagian ibu berpengetahuan kurang tentang pemeriksaan kehamilan.

2. Sebagian besar ibu melakukan kunjungan K1 Murni.

3. Ada hubungan yang signifikan antara pengetahuan ibu tentang pemeriksaan kehamilan pada trimester I dengan kunjungan K1 Murni di Bidan Praktek Swasta Hanik Surabaya.

Berdasarkan hasil penelitian diharapkan dapat digunakan sebagai sumber informasi bagi ibu hamil tentang pentingnya pemeriksaan kehamilan pada kehamillan trimester I yaitu untuk mencegah dan mendeteksi kelainan yang terjadi pada janin .

\section{DAFTAR PUSTAKA}

A Wawan, Dewi M. 2010. Teori dan Pengukuran Pengetahuan, Sikap, dan Perilaku Manusia. Jakarta : Nuha Medika

Depkes RI. 2007. Pedoman Pelayanan Antenatal. Jakarta : Depkes

Dinkes. 2010. Profile Kesehatan. Surabaya. Dinkes.

Dinkes. 2011. Profile Kesehatan. Dinkes.

Efendi, F. 2009. Keperawatan Kesehatan Komunitas : Teori dan Praktek dalam Keperawatan. Jukarta Salemba Medika

Henderson, C. 2009. Buku Ajar Konsep Kebidanan. Jakarta : EGC

Manuaba, Ida Bagus Gde dkk. 2010. IImu Kebidanan Penyakit Kandungan dan Keluarga Berencana. Jakarta : EGC.

Notoatmodjo Soekidjo 2007. IImu Perilaku dan Sikap. Jakarta : Rineka Cipta

Notoatmodjo, Soekidjo. 2008. Kesehatan Masyarakat IImu dan Seni. Jakarta : Rineka Cipta

Nursalam. 2008. Konsep dan Penerapan Metodologi Penelitian IImù Keperawatan. Salemba Medika: Jakarta.

Nursalam dan Pariani S. 2009. Pendekatan Praktis Metodologi Riset Keperawatan. Cetakan Pertama. Jakarta : Sagung Seto

Prawiroharjo, Sarwono. 2002. Buku Panduan Praktis Pelayanan 
Kesehatan Maternal dan Neonatal. Jakarta:YBP-SP

Prawirohardjo. 2005. IImu Kandungan. Jakarta : Yayasan Bina Pustaka Sarwono Prawiroharjo

Prawirohardjo. 2010. Ilmu Kebidanan. Jakarta : Bina Pustaka

Saifuddin. Abdul Bari. 2009. IImu Kebidanan. Jakarta : YBPSP

Saifuddin, Abdul Bari. 2010. Buku Panduan Praktis Pelayanan Kesehatan Maternal dan Neonatal. Jakarta : PT Bina Sarwono Prawirohardjo

Saminem. 2011. Dokumentasi Kebidanan Konsep dan Praktik. Jakarta : EGC

Sarlito Wirawan Sarwono. 2005. Psikologi Remaja. Jakarta : Rajawali 